DOI: 10.14526/2070-4798-2020-15-3-19-23

\title{
The educational component improving in greco-roman wrestling at the initial training stage
}

\author{
Aleksandr S. Kuznetsov, Zinaida M. Kuznetsova*, Stanislav A. Kuznetsov \\ Naberezhnye Chelny branch of Management University "TISBI" \\ Naberezhnye Chelny, Russia \\ ORCID: oooo-ooo3-4294-3755, kuznetsov-as@mail.ru \\ ORCID: oooo-0oo2-5558-474X,kzm_diss@mail.ru* \\ ORCID: oooo-0002-7708-0403, stanislav.kuznetsov.79@mail.ru
}

\begin{abstract}
The research relevance is determined by the desire to reduce the students' dropout rate and increase the educational process during Greco-Roman wrestling classes at the initial stage of training. Material. Increasing the motivational effect of Greco-Roman wrestling classes by introducing technical categories and increasing sports titles at the initial training stage. Research methods: analysis of normative documents, coaches 'survey, students' survey, pedagogical observations. Result. The pedagogical experiment in sports school on GrecoRoman wrestling participated athletes of the second and third years of study. It showed that in experimental groups, where technical categories were introduced, increased quantitative performance indicator (QtPI), an indicator of profitability (P), a qualitative performance indicator (QlPI). The increase of sports titles number reduced the dropout rate in comparison with the control groups with equal technical and tactical activity indicators. Conclusion. Technical and additional sports titles Introduction at the initial training stages has a positive effect on the quality of wrestlers' competitive activity.
\end{abstract}

Keywords: technical arsenal, technical category, quantitative performance indicator, qualitative performance indicator, winning, technical multidirectionality.

For citation: Kuznetsov A.S., Kuznetsova Z.M., Kuznetsov S.A. Increasing the educational component in Greco-Roman wrestling at the stage of initial training. Russian Journal of Physical Education and Sport. 2020; 15 (3): 15-18. DOI: 10.14526/2070-4798-2020-15-3-19-23

\section{INTRODUCTION}

The analysis of normative documents of sports schools (SSH) and sports schools of the Olympic reserve (SSHOR) on competitive activities in GrecoRoman wrestling, as well as a specialists' survey [3] indicate a significant dropout rate of athletes engaged in Greco-

Roman wrestling at the early stages of training. Some children drop out of wrestling due to understanding lack of awareness about the chosen sport content [5]. It is not correct to appeal only for children's inability of determination at the initial stage, as you cannot explain the dropouts in the next years of study (2nd, 3rd, 4th).

The dropouts' cases by athletes with high sports results are noted. The reason was the loss of interest in the type of activity due to the limited and monotonous educational material.

That's why various game exercises are used in sports where the technical actions volume is limited. They are aimed not at ensuring the athletes' versatile development, but at removing monotony.

In addition to functional overloads at an early age and the narrowness of the technical arsenal in Greco-Roman wrestling, there is also a loss of entertainment, which negatively effects on mass appeal.

We surveyed children who quit Greco-Roman wrestling. There are practically no incentives to master the technical arsenal in such a complex type of activity as Greco-Roman wrestling. Therefore, there is a need to introduce organizational incentives that would allow long-term motivation of cognitive and sports activities at different stages of training.

There are scientific publications on the role of motivation in Greco-Roman wrestling [4], but they put such motives in the first place as:

- desire to become a champion;

- get a financial reward.

In the conditions of early specialization in

Greco-Roman wrestling, it is necessary to take into account motivational factors such as:

- the desire to learn how to perform techniques (educational component);

- get a sports title (to ensure your social status).

Children at an early age urge to learn and master a wide range of motor skills and cannot focus on the delayed effect [1]. Thus it is advisable to publicly record the achievements of athletes as often as possible. In addition to the sports qualification it is necessary to introduce a technical qualification for the mastery of techniques, as is done in the Eastern 
types of martial arts.

The unified all-Russian sports classification

[2] requires:

- in boxing, the qualification provides participation in meetings and the number of wins, and the assignment of sports titles begins with the 3rd Class Junior level;

- in all types of gymnastics exercises, getting a sports title depends on performing a certain list of gymnastic elements and their bundles, in a certain category of difficulty. The assignment of a sports title begins with a young gymnast;

- in various types of athletics, you need to achieve results in seconds, meters, etc.to get a sports title;

- in Greco-Roman wrestling, the assignment of titles is set only for a certain number of victories. Assignment of sports categories begins with the 2nd Class Junior level;

No matter what technical arsenal the wrestler uses to achieve these victories. Thus, many high-class wrestlers use only one technique. In this case, the highest sports result is achieved only at the expense of functional overstrain.

Focusing on such wrestlers, coaches (especially national teams) put increasing physical capabilities at the head of the pre-competition training strategy. This knocks out wrestlers with an average level of current physical development from the team and deprives the leading wrestlers of sparring partners.
It leads to a decrease in the variability of technical and tactical readiness of team members. These factors compound the problem even more.

The goal of the research: to increase the motivational effect by qualification assessment of the software technical arsenal mastery degree by introducing technical categories (table 1) and by increasing the number of sports titles at the stages of initial training (table 2).

\section{RESULTS AND DISCUSSION}

The pedagogical experiment in sports school on Greco-Roman wrestling participated athletes of the second and third years of study. It was found that in the experimental groups where technical categories were introduced and technical standards were officially passed, the quantitative performance indicator (QtPI) increased $(\mathrm{p}<0.01)$, win rate $(\mathrm{W})$ $(\mathrm{p}<0.01)$, quality performance indicator (QlPI) ( $<$ 0.05). The correlation analysis results showed a direct dependence of the resulting indicators growth of technical and tactical skill on the technical diversity indicator (DTec). It indicates a positive impact of "forced" incentives to technical diversity.

In the experimental groups, where the number of sports titles was increased, the dropout rate decreased by 56 percent compared to the control groups, with equal indicators of technical and tactical activity $(\mathrm{p}>0.05)$.

Table 1. The content of the technical categories

\begin{tabular}{|c|c|c|}
\hline Category & $\begin{array}{l}\text { Stripes on } \\
\text { singlet }\end{array}$ & $\begin{array}{l}\text { Requirements content for wrestling techniques } \\
\text { demonstration (stand, groundwork): }\end{array}$ \\
\hline 8-th & White & $\begin{array}{l}\text { - throws in } 4 \text { diagonal directions; } \\
\text { - flips in } 4 \text { longitudinal and transverse directions (according to the }\end{array}$ \\
\hline 7-th & Yellow & $\begin{array}{l}\text { program); } \\
\text { - newly studied flips in } 4 \text { longitudinal-transverse directions; } \\
\text { Arm throws. }\end{array}$ \\
\hline 6-th & Green & $\begin{array}{l}\text {-throws in } 4 \text { diagonal directions; } \\
\text { - flips in } 4 \text { longitudinal and transverse directions in dynamic } \\
\text { situations at the command of the judge. }\end{array}$ \\
\hline 5 -th & Blue & - throws, arm throws and flips in combinations. \\
\hline 4-th & Orange & - throws, flips and flips from stand and capture pre-change. \\
\hline $3-\mathrm{d}$ & Red & $\begin{array}{l}\text { - throws, flips, and flips in conditions of non-standard mutual poses } \\
\text { and captures. }\end{array}$ \\
\hline 2-nd & Brown & $\begin{array}{l}\text { - technical and tactical actions demonstration with opponents of } \\
\text { various fighting styles. }\end{array}$ \\
\hline 1-st & Black & $\begin{array}{l}\text { - technical and tactical actions demonstration when changing mutual } \\
\text { poses (in wrestling units). }\end{array}$ \\
\hline
\end{tabular}


Table 2. The requirements to sports titles

\begin{tabular}{|c|c|}
\hline Title & Requirements \\
\hline Young wrestler & 4 wins over novices \\
\hline 3d-Class Junior athlete & $\begin{array}{l}\text { - } 6 \text { wins over young wrestler; } \\
-3 \text { wins over } 3 \text { d-Class Junior athlete. }\end{array}$ \\
\hline 2nd-Class Junior athlete & $\begin{array}{l}\text { - } 8 \text { wins over } 3 \text { d-Class Junior athlete; } \\
\text { - } 4 \text { wins over } 2 \text { nd-Class Junior athlete. }\end{array}$ \\
\hline $1^{\text {st_Class Junior athlete }}$ & $\begin{array}{l}\text { - } 10 \text { wins over } 2 \text { nd-Class Junior athlete; } \\
\text { - } 5 \text { wins over } 1 \text { st-Class Junior athlete. }\end{array}$ \\
\hline 3d-Class athlete & $\begin{array}{l}\text { - } 12 \text { wins over } 1 \text { st-Class Junior athlete; } \\
\text { - } 6 \text { wins over } 3 \text { d-Class athlete. }\end{array}$ \\
\hline $2^{\text {nd }}$-Class athlete & $\begin{array}{l}-12 \text { wins over } 3 \mathrm{~d} \text {-Class athlete; } \\
-6 \text { wins over } 2 \text { nd-Class athlete. }\end{array}$ \\
\hline $1^{\text {st }}$ Class athlete & $\begin{array}{l}\text { - } 12 \text { wins over } 2 \text { nd-Class athlete; } \\
-6 \text { wins over } 1 \text { st-Class athlete. }\end{array}$ \\
\hline Candidate Master of Sports & $\begin{array}{l}\text { - } 10 \text { wins over 1st-Class athlete and } 2 \text { wins over Candidate Master of } \\
\text { Sports }\end{array}$ \\
\hline Master of Sport & $\begin{array}{l}\text {-The win in the all-Russian tournament, provided that athletes from } \\
\text { at least five regions and at least five Masters of Sports of Russia take } \\
\text { part in the tournament; } \\
\text { - The wins at the Federal district Championships. }\end{array}$ \\
\hline $\begin{array}{l}\text { Master of Sport of International } \\
\text { Class }\end{array}$ & $\begin{array}{l}\text { - The win at the Russian championship; } \\
\text { - The win in an International Tournament included in the calendar of } \\
\text { the international UWW FEDERATION }\end{array}$ \\
\hline Merited Sports Master & $\begin{array}{l}\text { - The win at the World Championship; } \\
\text { - 1-3 place at the Olympic games. }\end{array}$ \\
\hline
\end{tabular}

A comparative analysis of the occupancy rate of the experimental and control groups indicates a significant decrease in the dropout rate from the experimental groups.

\section{Conclusion}

The technical categories introduction as means of stimulating to increase technical diversity and the introduction of additional sports titles at the initial training stage positively affects the wrestlers' competitive activity, as well as the participants ' contingent retention.

\section{REFERENCES}

1. Gorskaya G. B. Psychological support for longterm training of athletes. Krasnodar. 1995: 68. [In Russ.]

2. Unified all - Russian sports classification 20192022. M.: Physical culture and sport. 2019: 283. [In Russ.]

3. Kuznetsov A. S. Organizational and methodological bases of technical and tactical training in Greco-Roman style wrestlers: author's thesis... doctor of pedagogical Sciences. Krasnodar: KGAFK. 2002: 41. [In Russ.]

4. Piloyan R. A. Motivation and performance improvement in sports. Wrestling: Yearbook. Moscow. 1981: 70-72. [In Russ.]

5. U. A. Shulika, T. A. Gaiduk. Motivational aspect of ensuring mass physical culture in secondary schools. Modern problems of development of physical culture and biomechanics of sport: materials of the international scientific conference. Maykop. 1999: 166-171. [In Russ.]

6. Kuznetsov S.A., Kuznetsova Z.M. The history of the development of paralympic sports in the world. Russian Journal of Physical Education and Sport. 2014; 9 (2): 46-53. DOI 10.14526 / 00_1111_o6. URL: $\quad$ http://www.journal-science.org/ru/ magazine/2.html

7. Kuznetsova Z., Kuznetsov A., Mutaeva I., Khalikov G., Zakharova A., 2015. Athletes preparation based on a complex assessment of functional state. In Proceedings of the 3rd International Congress on Sport Sciences Research and Technology support. 
SCITEPRESS. P. 156-160 (Scopus)

8. Kuznetsov A., Mutaeva I., Kuznetsova Z. Research and Technology support. SCITEPRESS. Diagnostics of Functional State and Recerve Capacity of young Athletes' Organizm. In Proceedings of the 5th International Congress on Sport Sciences P. 111-115 (Scopus)

\section{Submitted: 27.07.2020}

\section{Author's information:}

Alexander S. Kuznetsov - Doctor of Pedagogical Sciences, Professor, Naberezhnye Chelny Branch of the HEI "University of Management" TISBI ", 423806, Russia, Naberezhnye Chelny, Komsomolskaya embankment, building 6, e-mail:, kuznetsov-as@mail.ru.

Zinaida M. Kuznetsova - Doctor of Pedagogy, Professor, Naberezhnye Chelny Branch of the HEI "University of Management" TISBI ", 423806, Russia, Naberezhnye Chelny, Komsomolskaya embankment, building 6, e-mail: kzm_diss@mail.ru

Stanislav A. Kuznetsov - Candidate of Pedagogy, Associate Professor, Naberezhnye Chelny Branch of the HEI "University of Management" TISBI ", 4238o6, Russia, Naberezhnye Chelny, Komsomolskaya embankment, building 6, e-mail: stanislav.kuznetsov.79@mail.ru 